\title{
Predictors of Entrepreneurial Orientation: Comparative Assessment of the Effects of Personality and Environment
}

\author{
Ahmet Emre Demirci (Corresponding Author) \\ Department of Business Administration, Faculty of Economics and Administrative Sciences \\ Anadolu University, Turkey \\ E-mail: aedemirci@anadolu.edu.tr
}

Received: January 6, 2020 Accepted: March 28, 2020 Published: April 10, 2020

doi:10.5296/ber.v10i2.16616ＵRL: https://doi.org/10.5296/ber.v10i2.16616

\begin{abstract}
This study aims to understand whether the personal traits or the environmental conditions play a more significant role in entrepreneurial intentions. Since intentions are strong predictors of the behaviors, it is important to understand whether the former or the latter factor has a stronger impact on entrepreneurial dispositions. In order to understand the complex relations between entrepreneurial intentions, personality traits, and perceived environmental conditions, total number of 229 economics and business administration students at Anadolu University, Faculty of Economics and Administrative Sciences were surveyed. Results of the statistical analysis have revealed that although the majority of the individual personal traits and contextual factors are perceived as strong predictors of entrepreneurial intentions, when considered as separate holistic structures; personal traits are better predictors for entrepreneurial intentions compared to contextual factors in Turkey.
\end{abstract}

Keywords: Entrepreneurship, Entrepreneurial intentions, Personality traits, Environmental conditions, Contextual factors

\section{Introduction}

There has been a growing interest and support in Turkey and across the world for entrepreneurship as an attractive but challenging alternative to public or private sector employment in the last two decades. There are several important causes of this trend including the need for innovative entrepreneurial activities in order to support economic development, shrinking demand for workforce in both private and public sectors, and relatively high unemployment rates especially among new graduates in Turkey. Turkish 
government has addressed these issues and taken few measures to support entrepreneurship in the country. For example, for the last seven years, TUBITAK (The Scientific and Technological Research Council of Turkey) has been ranking universities based on their entrepreneurship and innovation performances. The main purpose of such ranking is to enhance the entrepreneurship and innovation-based competition and improve the entrepreneurial climate in the Turkish universities. Furthermore, government has been expanding the scope of the support mechanisms for entrepreneurship and innovation through several governing bodies. However, exemplified and all other measures taken by the government are still not sufficient enough to multiply the entrepreneurial and innovative performance of the country. Besides, albeit these measures, according to GEM (Global Entrepreneurship Monitor) 2018-2019 Report, TEA (Total Early-Stage Entrepreneurial Activity) rate of Turkey has shown a slow and steady decline since 2015. However, due to new entrepreneurial policies introduced by the government to support high and medium-technology entrepreneurship that focuses more on the quality of the entrepreneurial activities rather than the quantity, the percentage of TEA entrepreneurs active in technology sectors increased significantly in the last few years (GEM Report, 2018-2019).

In addition to macro factors that enhance or hinder entrepreneurial activities, there are also micro or individual factors that should be considered when studying entrepreneurship. According to Schwarz et al. (2009), entrepreneurial intention has proven to be a major predictor for potential entrepreneurial initiatives. Thus, it is important to understand the underlying individual and environmental factors that shape entrepreneurial intentions.

This study focuses on the entrepreneurial intentions and how these intentions are shaped by the personality traits and perceived environmental conditions. Specifically, we analyzed the effects of personality traits such as need for achievement, internal locus of control, and entrepreneurial self-efficacy on entrepreneurial intentions. Furthermore, we also analyzed how perceived environmental conditions such as support mechanisms and access to financing would affect entrepreneurial intentions.

\section{Entrepreneurial Intentions}

Entrepreneurial intentions can be considered as individual orientations that could possibly lead to entrepreneurial initiatives. For Fayolle and Linan (2014), entrepreneurial intention is the motive that leads an individual to pursue a self-employment career or start his or her own business. Van Gelderen (2008) defines entrepreneurial intention as the intentions of setting up one's own business in the future. Similarly, Engle et al. (2010) defines entrepreneurial intention as an individual's intention to start a new business. According to Marire, Mafini, and Dhurup (2017) entrepreneurial intention is defined as an individual's enthusiasm to be engaged in self-employment, starting a new business or to participate and accomplish an entrepreneurial initiative. They also suggest that the option of starting a new business and choosing entrepreneurship as a career depend heavily on intentional preparation, planning, and thinking. Moreover, entrepreneurial intention is affected by the personality traits and perceived environmental conditions. Krueger (1993) suggests that entrepreneurial intentions are very crucial to understand the entrepreneurship process since they form the underpinnings 
of the new organizations. It must also be understood that entrepreneurial process is relatively a long journey. Thus, having entrepreneurial intentions could be viewed as the initial step in this evolving and long process.

An important question is about where intentions come from. Krueger (2017) claims that a conventional wisdom that intentions are the consequence of a process that was reasonably well understood by social and cognitive psychology was widely accepted. However, Krueger (2017) claims that a closer look at the entrepreneurial intentions reveals that such intentions may need to be re-conceptualized at a more fundamental level. According to Fishbein and Ajzen (1975) intentions are considered as a function of beliefs that provide a direct link between beliefs and behavior. That is, people form attitudes toward performing a given behavior based on beliefs that performing the behavior will result in certain consequences, as well as normative beliefs about the behavior. Behavioral intention results from attitudes and becomes the immediate determinant of behavior (Boyd and Vozikis, 1994). Figure 1 shows this relationship.

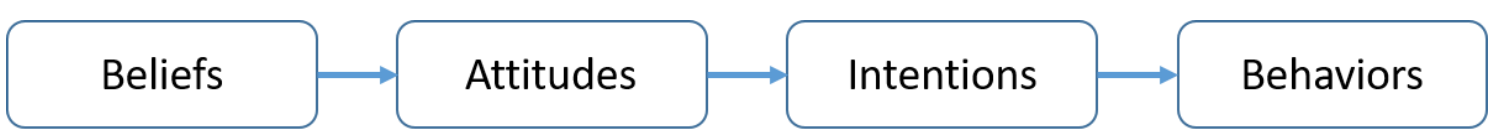

Figure 1. Link Between Beliefs and Behaviors

Source: Adapted from Fisbein and Ajzen (1975)

Parallel with Fishbein and Ajzen's (1975) view, our research conceives of intentions as the consequence of certain antecedents that could be classified in two categories: personality traits and perceived environmental conditions.

Perceived environmental conditions refer to a large set of contextual factors that can potentially have an impact on the intention to engage in entrepreneurial activities. Mainly educational support, structural support, formal support, and informal support are among the major contextual factors that might affect entrepreneurial intention. People would most likely to engage in entrepreneurial activities when they perceive their environment as favorable for starting a new business. Such an impact is known as trigger effect. When people perceive that there are business opportunities such as easy access to financial resources, availability of market information and etc., they are more likely to show entrepreneurial behaviors and start a new business. However, as a result of negative perceptions regarding the business environment, they might behave more reluctantly to start their businesses. Lack of market information, lack of knowledge on writing a business plan, not having access to financial resource, and lack of knowledge on business management may be mentioned among the negative issues that might slow down or inhibit entrepreneurial initiatives (Ismail et al., 2009).

On the other hand, personality traits refer to an individual's enduring dispositions, inclinations or tendencies that lead to certain attitudinal and behavioral patterns across 
situations (Chen, Su and Quyet, 2017). Similarly, according to Saroglou and Munoz-Garcia (2008), personality traits are defined as behavioral ways of responding through cognitions, emotions, and actions. De Pillis and Reardon (2007) suggest that personality traits are proven to be an intriguing but imperfect predictors of many entrepreneurial aspects including intending to start a new business, running an existing business successfully, and engaging in intrapreneurial activities. Similarly, Gartner (1988) notes that, according to trait approach, entrepreneurs possess a specific set of personality traits albeit he has few concerns about this approach. Our study considers three major personality traits that are closely related with entrepreneurial intention and entrepreneurial activities: need for achievement, internal locus of control, and entrepreneurial self-efficacy.

\section{Personal Traits}

\subsection{Need for Achievement}

Need for achievement is among the most studied personality characteristics in entrepreneurship research. Need for achievement has a great potential to trigger the entrepreneurial initiatives (Demirci, 2013). Because the need for achievement is an unconscious motive that drives individuals to perform better and improve their existing performance that in return creates some personal excellence standards (Loon and Casimir. 2008). According to Jackson (1974), a person with high need for achievement is someone who maintains high standards and aspires to accomplish difficult tasks. Furthermore, the achievement motive is based on expectations of doing something better or faster than anybody else or better than the individual's earlier successes or achievements (Hansemark, 1998). Hansemark (1998) also suggests that the development of the need for achievement motive occurs by how the person's existing frame of reference is put against the person's own desire to achieve. In that way, the need for achievement motive will be a process of planning and striving for excellence. McClelland noted that the need for achievement is culturally acquired and it is an integral psychological quality of an entrepreneur. An individual with a high need for achievement motivation is characterized as (McClelland, 1967);

(a) taking personal responsibility for her/his decisions,

(b) setting goals and accomplishing them through her/his effort, and

(c) having a desire for feedback

Numerous studies concerning the need for achievement have revealed that the correlation between need for achievement and entrepreneurship is much stronger (Gurol and Atsan, 2006). Although achievement motivation itself merely is not enough to completely explain why an individual choose an entrepreneurial career path, it is generally considered as a key component (Cover and Johnson, 1976). McClelland explains the interaction between entrepreneurial actions and achievement motivation by the statement below:

“[...] a high need for achievement predisposes a person to seek out an entrepreneurial position in order to attain more achievement satisfaction than could be derived from other types of positions - those which are more managerial." 
According to Locke and Latham (1994) individuals with high need for achievement motivation tend to believe that they have control over the outcome of their behavior and that they have reliable feedback about their progress toward their goals. It is obvious that such a motivation plays an integral role in entrepreneurial behavior. Holland (1985) suggests that an entrepreneurial career path offers more opportunities to take advantage of the personal characteristics associated with high need for achievement motivation. Thus, individuals with high need for achievement motivation are more likely to have a disposition toward entrepreneurial careers. However, it is important to note that high need for achievement motivation, isolated from other variables, might be a weak predictor of an individual's tendency to start a new business (Cunningham and Lischeron, 1991). Thus, other variables should be taken into account when predicting one's entrepreneurial inclinations.

\subsection{Internal Locus of Control}

Identical with the previous entrepreneurial attitudes, locus of control could also be considered as one of the most dominant characteristic of entrepreneurs. Internal locus of control is about knowing that the individual himself/herself is responsible for the outcomes of the decisions (s)he made (Demirci, 2013). Evans and Leighton (1989) suggest that the psychological theory based on the internal locus of control is consistent with their research findings and self-employed individuals at a point in time tend to have a higher internal locus of control and people with higher internal locus of control are more likely to enter self-employment. People with high internal focus of control believe that they are able to control the outcomes. Thus, they tend to put their best efforts and show persistence towards their goals that in return facilitates the start-up process and later entrepreneurial steps (Rauch and Frese, 2007). On the other hand, people with high external locus of control tend to believe that the outcomes are controlled by the forces outside her/him. Rotter (1966) notes that the internal locus of control is related with learning, and thus drives and encourages active effort. However, external locus of control hinders learning and drives passivity. Thus, an internal locus of control is more likely to be a part of entrepreneurial qualities. The main reason behind the relationship between entrepreneurship and internal locus of control is that people who attribute responsibility for their performance to themselves tend to assume that they can cause certain changes in their environment, which in turn leads to an increase in their motivation (Anderson, 1977).

\subsection{Entrepreneurial Self-Efficacy}

In addition to the previous personality traits that have impact on entrepreneurial intention, entrepreneurial self-efficacy is another trait that needs to be taken into account. In the social-cognitive theory (SCT), self-efficacy is considered to be a central mechanism of personal agency. According to SCT, self-efficacy influences an individual's level of effort and persistence on a specific task as well as her/his choices of activities and behavioral settings. In that case, low self-efficacy perceptions lead individual to avoid these activities and behavioral settings (Zhao, Seibert and Hills, 2005). Gist (1987) defines self-efficacy as an individual's belief in her or his capability to perform a task - that has a direct impact on the initiative of starting a new business. According to Boyd and Vozikis (1994) self-efficacy 
influences an individual's belief that whether or not (s)he will be able to attain her/his goals and thus, choices, aspirations, effort, and perseverance in the face of setbacks are all influenced by the self-perception of one's own capabilities. In other words, if the person perceiving a task or behavior beyond her/his abilities, (s)he will not engage in the task or behavior even if there is a perceived social demand for the behavior. Chen, Greene and Crick (1998) found that entrepreneurial self-efficacy is a predictor of entrepreneurial intention and people with high entrepreneurial self-efficacy perception tend to show more entrepreneurial characteristics. Entrepreneurial self-efficacy is particularly useful in measuring entrepreneurial intentions since it involves personality as well as environmental factors and thus, considered to be an important predictor of entrepreneurial intentions and consequently entrepreneurial actions (McGee et al., 2009).

Since entrepreneurial self-efficacy is more of a broad and complex conceptualization, Barbosa, Gerhardt and Kickul (2007) note that it would be composed of several task-specific types of self-efficacy: Opportunity-identification self-efficacy, relationship self-efficacy, managerial self-efficacy, and tolerance self-efficacy. According to Barbosa, Gerhardt and Kickul (2007);

- Opportunity-identification self-efficacy refers to the person's perceived self-efficacy concerning her/his abilities to identify and develop new product and market opportunities.

- Relationship self-efficacy refers to the person's perceived self-efficacy concerning her/his abilities to build relationships - especially with potential investors and other important stakeholders.

- Managerial self-efficacy refers to the person's perceived self-efficacy concerning her/his abilities to manage a business and make managerial decisions.

- Tolerance self-efficacy refers to the person's perceived self-efficacy concerning her/his abilities to work effectively and efficiently under stress, pressure, conflict, and change.

It is clear that all these types of the entrepreneurial self-efficacy perceptions play an integral role in entrepreneurial intentions.

\section{Contextual Factors}

\subsection{Educational Support}

Entrepreneurship education and entrepreneurial universities have become a focal point for both academics and policymakers in the last two decades. Universities are important since they play an integral role in identifying and developing entrepreneurial traits and dispositions among students and making them capable of starting their own businesses. By doing so, universities contribute to economic development and job creation (Saeed et al., 2015). Chen, Greene and Crick (1998) also suggest that entrepreneurship education is closely linked with enhanced attitudes and inclinations toward starting a new business. Kolvereid and Moen (1997) note that, according to their research, students who have taken entrepreneurship 
courses during their studies showed more interest in starting a new business compared to those who have not taken any entrepreneurship courses. In addition to educational programs, a supportive entrepreneurial environment provided by the universities can also encourage students' entrepreneurial intentions (Hussain, 2018).

\subsection{Structural Support}

Although educational programs and entrepreneurial environment provided by the universities are important predictors of entrepreneurship intentions, it is important to note that other predictors should be taken into account. Among these predictors, structural support is important for encouraging individuals to start their own businesses. Structural support refers to the support from government and institutions like banks and others in creating entrepreneurs (Shankar, 2014). Such support includes regulations, level of bureaucracy, financial support, taxation, and other factors put in place to develop entrepreneurship (Khoshmaram et al., 2018).

\subsection{Formal and Informal Support}

Formal and informal networks mainly involve formal and informal networks. Networks include social relationships, family, friends, neighbors, as well as customers, vendors, and creditors (Gelard and Saleh, 2011). While informal support includes support from informal actors such as family and friends, formal support includes support from formal resources such as investors, consultants, and vendors.

Aldrich and Zimmer (1986) note that entrepreneurs must build connections and networks to access resources and at some point they are affected by relations with socializing agents who motivated them. They also claim that the relations with the formal and informal networks occur in three possible settings:

a. Communication content, or exchanging information among the members of the network,

b. Exchange content, or the goods and services people can exchange,

c. Normative content or the expectations persons have of one another because of some special attributes.

Birley (1985) suggests that the main sources of assistance in gathering the resources for the start-up is attained from informal networks including family, friends, and colleagues. The only organization that was mentioned in Birley's (1985) research was the bank, which was approached toward the end of the establishment process when majority of the resources were already assembled. However, Birley (1985) warns entrepreneurs about the availability of other formal actors through which entrepreneurs attain various resources.

\section{Research Design and Methodology}

\subsection{Research Hypotheses}

This research aims to understand whether the personal traits or the environmental conditions 


\section{Al Macrothink}

Business and Economic Research

ISSN 2162-4860

2020, Vol. 10, No. 2

play a more significant role in entrepreneurial intentions. Since intentions are strong predictors of the behaviors, it is important to understand whether the former or the latter factor has a stronger impact on entrepreneurial dispositions.

Traits school of entrepreneurship considers entrepreneurs as individuals with unique values and attitudes that differentiate them from non-entrepreneurs. Individual needs, attitudes, beliefs and values can be considered as the primary determinants of the human behavior (Koh, 1996). It could be argued that culture is an underlying factor that shapes human behavior and personality traits. Studies on entrepreneurship have shown that several traits could be attributed to entrepreneurial personality. Although there are numerous personality traits directly linked with entrepreneurship, this study focuses on three major personality traits including need for achievement, internal locus of control, and entrepreneurial self-efficacy.

On the other hand, contextual factors such as the demographics, educational support, structural support, formal support, and informal support are more likely to affect entrepreneurial intentions. Thus, whether the factors provided by the traits school of entrepreneurship or the contextual factors have a stronger impact on entrepreneurial intentions is the key question in this research. Figure 2 shows the research model adopted to understand these relations between given variables.

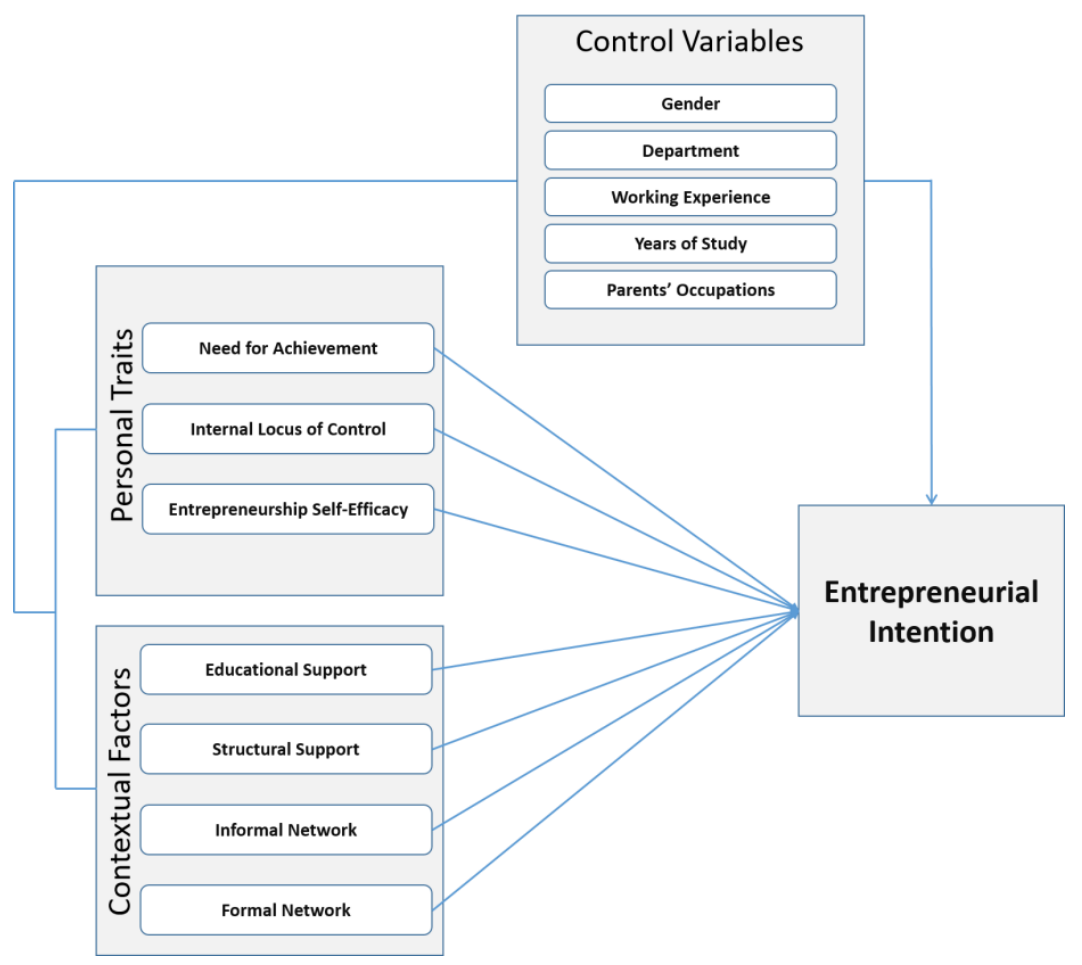

Figure 2. Research Model

Hypotheses given below (Table 1) were tested in order to determine whether the personality traits or the perceived contextual factors play a more integral role in determining entrepreneurial intentions. 
Table 1. Research Hypotheses

\begin{tabular}{|l|l|}
\hline $\mathbf{H}_{\mathbf{1}}$ & $\begin{array}{l}\text { People with higher need for achievement motivation are more likely to have a stronger } \\
\text { intention to become entrepreneurs. }\end{array}$ \\
\hline $\mathbf{H}_{\mathbf{2}}$ & $\begin{array}{l}\text { People with higher internal locus of control are more likely to have a stronger intention } \\
\text { to become entrepreneurs. }\end{array}$ \\
\hline $\mathbf{H}_{\mathbf{3}}$ & $\begin{array}{l}\text { People with higher entrepreneurial self-efficacy are more likely to have a stronger } \\
\text { intention to become entrepreneurs. }\end{array}$ \\
\hline $\mathbf{H}_{\mathbf{4}}$ & $\begin{array}{l}\text { Availability of perceived educational support have positive impact on entrepreneurial } \\
\text { intentions. }\end{array}$ \\
\hline $\mathbf{H}_{5}$ & $\begin{array}{l}\text { Availability of perceived structural support have positive impact on entrepreneurial } \\
\text { intentions. }\end{array}$ \\
\hline $\mathbf{H}_{\mathbf{6}}$ & $\begin{array}{l}\text { Availability of perceived informal support have positive impact on entrepreneurial } \\
\text { intentions. }\end{array}$ \\
\hline $\mathbf{H}_{7}$ & $\begin{array}{l}\text { Availability of perceived formal support have positive impact on entrepreneurial } \\
\text { intentions. }\end{array}$ \\
\hline $\mathbf{H}_{\mathbf{8}}$ & $\begin{array}{l}\text { Personal traits have higher positive impact on entrepreneurial intentions compared to } \\
\text { contextual factors. }\end{array}$ \\
\hline
\end{tabular}

\subsection{Research Sample}

As this research focuses on testing the effects of personal traits and contextual factors on entrepreneurship intentions subjects were drawn from a younger population with a possible tendency and background to become entrepreneurs rather than the actual entrepreneurs.

Due to their academic background, research subjects were drawn among the students enrolled in Business Administration, Economics, Public Finance, and Labor Economics and Industrial Relations programs at Anadolu University (Turkey). The subjects were considered to be exposed more to the entrepreneurship trainings and curriculum in order to develop relevant skills.

As a secondary criterion, subjects were drawn among the third and fourth year undergraduate students due to the assumption that senior undergraduate students have a better understanding of the concepts related with entrepreneurship. Curricula of the programs involved in the research were reviewed in order to support this and it was found that all programs offer considerable number of formal courses related to entrepreneurship. It was also found that there are many extracurricular activities organized at Anadolu University that potentially effects students' entrepreneurial intentions.

Total number of 229 usable surveys collected from the students of Anadolu University, Faculty of Economics and Administrative Sciences.

\subsection{Research Instrument}

The measures identified as antecedents of entrepreneurial intentions were based on the trait approach and contextual factors approach in entrepreneurship research. In order to measure 


\section{Macrothink}

Business and Economic Research

ISSN 2162-4860

2020, Vol. 10, No. 2

need for achievement, the scale adopted by Ören and Biçkes (2011). Internal locus of control scale was adapted from the scale developed by Levenson (1981). Entrepreneurial self-efficacy scale was taken from Cox, L.W., Mueller, S.L., \& Moss (2002). Contextual factors including educational support, structural support, formal and informal networks was measured with the scale developed by Gelard and Saleh (2011). Finally, entrepreneurial intention scale was adapted from the scale used by Botsaris and Vamvaka (2016). Total number of 45 questions were asked to the subjects in order to analyze the relationship between personality traits, contextual factors, demographics, and entrepreneurial intentions. Breakdown of the number of questions for each factor is given below:

- Entrepreneurial intentions (7 items)

- $\quad$ The need for achievement (6 items)

- Internal locus of control (6 items)

- Entrepreneurial self-efficacy (10 items)

- Contextual factors:
- Educational support (3 questions)
- Structural support (4 questions)
- Informal support (5 questions)
- Formal support (4 questions)

Our Cronbach's alpha values for each measure and for the overall scale are given below.

Table 2. Cronbach's Alpha Values

\begin{tabular}{|l|l|}
\hline Measure & Cronbach's Alpha Value \\
\hline Entrepreneurial intentions & .93 \\
\hline The need for achievement & .75 \\
\hline Internal locus of control & .68 \\
\hline Entrepreneurial self-efficacy & .90 \\
\hline Educational support & .89 \\
\hline Structural support & .79 \\
\hline Informal support & .85 \\
\hline Formal support & .87 \\
\hline
\end{tabular}

Cronbach's alpha value for the overall scale is .91 . These values show that the instruments used in the study are valid, reliable and internally consistent.

For the study, translated versions of the measures were distributed to the subjects. Translation into Turkish was considered in order to maintain a better understanding of the context of the measures by the students as they were not native in English. In order to increase the reliability of the translation, a translator native in English and fluent in Turkish has 


\section{Macrothink}

Business and Economic Research ISSN 2162-4860 2020, Vol. 10, No. 2

back-translated the measures into English to confirm the reliability of the first translation. An expert in the relevant field reviewed the back-translated version with the researcher.

\subsection{Research Findings}

Descriptive statistics and correlations among the variables concerning entrepreneurial intentions and personal traits are presented in Table 3, 4, and 5. The tables shows that variables used for this study are internally consistent and there are statistically significant relations between the variables. As shown in the table, we can suggest that the research subjects have made over-average statements regarding the relations between innovativeness and different organizational cultures.

Table 3. Descriptive Statistics

\begin{tabular}{|l|l|l|l|l|l|}
\hline Gender & Frequency & Percent & Working Experience & Frequency & Percent \\
\hline Female & 108 & $47.2 \%$ & Yes & 142 & $62 \%$ \\
\hline Male & 121 & $52.8 \%$ & No & 87 & $38 \%$ \\
\hline Total & $\mathbf{2 2 9}$ & $\mathbf{1 0 0 \%}$ & Total & $\mathbf{2 2 9}$ & $\mathbf{1 0 0 \%}$ \\
\hline
\end{tabular}

\begin{tabular}{|l|l|l|l|l|l|}
\hline Years at School & Frequency & Percent & Department & Frequency & Percent \\
\hline $\mathbf{2}$ & 38 & $16.6 \%$ & Business Adm. & 161 & $70.3 \%$ \\
\hline $\mathbf{3}$ & 89 & $38.9 \%$ & Other (FEAS) & 68 & $29.7 \%$ \\
\hline $\mathbf{4}$ or more & 102 & $44.5 \%$ & Total & $\mathbf{2 2 9}$ & $\mathbf{1 0 0 \%}$ \\
\hline Total & $\mathbf{2 2 9}$ & $\mathbf{1 0 0 \%}$ & & & \\
\hline
\end{tabular}

\begin{tabular}{|l|l|l|l|l|l|}
\hline $\begin{array}{l}\text { Mother's } \\
\text { Occupation }\end{array}$ & Frequency & Percent & $\begin{array}{l}\text { Father's } \\
\text { Occupation }\end{array}$ & Frequency & Percent \\
\hline None & 69 & $30.1 \%$ & None & 17 & $7.4 \%$ \\
\hline Business Owner & 90 & $39.3 \%$ & Business Owner & 80 & $34.9 \%$ \\
\hline $\begin{array}{l}\text { Public/Private } \\
\text { Sector }\end{array}$ & 70 & $30.6 \%$ & $\begin{array}{l}\text { Public/Private } \\
\text { Sector }\end{array}$ & 132 & $57.6 \%$ \\
\hline Total & $\mathbf{2 2 9}$ & $\mathbf{1 0 0 \%}$ & Total & $\mathbf{2 2 9}$ & $\mathbf{1 0 0 \%}$ \\
\hline
\end{tabular}

Table 4. Correlations among the research variables (Between Entrepreneurial Intentions and Personal Traits)

\begin{tabular}{|l|l|l|l|l|l|}
\hline Variables* & Mean & ENT_INT & NfA & LoC & ENTRE_SE \\
\hline ENTRE_INT & 3.3244 & 1 & $.349^{* *}$ & $.244^{* *}$ & $.689^{* *}$ \\
\hline NfA & 3.6638 & & 1 & $.535^{* *}$ & $.448^{* *}$ \\
\hline LoC & 3.7962 & & & 1 & $.373^{* *}$ \\
\hline ENTRE_SE & 3.6782 & & & & 1 \\
\hline
\end{tabular}

**. Correlation is significant at the 0.01 level (2-tailed). 


\section{Macrothink}

Business and Economic Research ISSN 2162-4860 2020, Vol. 10, No. 2

ENTRE_INT: Entrepreneurial Intentions NfA: Need for Achievement LoC: Locus of Control ENTRE_SE: Entrepreneurial Self-Efficacy

Descriptive statistics and correlations among the variables concerning entrepreneurial intentions and contextual factors are presented in Table 5.

Table 5. Correlations among the research variables (Between Entrepreneurial Intentions and Contextual Factors)

\begin{tabular}{|l|l|l|l|l|l|l|}
\hline Variables* & Mean & ENT_INT & EDU_SUP & STR_SUP & INF_SUP & FOR_SUP \\
\hline ENTRE_INT & 3.3244 & 1 & $.211^{* *}$ & .012 & $.218^{* *}$ & $.313^{* *}$ \\
\hline EDU_SUP & 3.0771 & & 1 & $.228^{* *}$ & $.175^{* *}$ & $.144^{*}$ \\
\hline STR_SUP & 2.7227 & & & 1 & .117 & .077 \\
\hline INF_SUP & 4.0559 & & & & 1 & $.558^{* *}$ \\
\hline FOR_SUP & 4.0939 & & & & & 1 \\
\hline
\end{tabular}

**. Correlation is significant at the 0.01 level (2-tailed).

ENTRE_INT: Entrepreneurial Intentions EDU_SUP: Educational Support STR_SUP: Structural Support INF_SUP: Informal Support FOR_SUP: Formal Support

As seen in Table 5, Structural Support has no statistically significant correlation with entrepreneurial intentions. Thus, structural support will not be included in further statistical analysis.

Table 6 shows the results of the multiple linear regression results for entrepreneurial intentions and personal traits.

Table 6. Results of the multiple linear regression concerning entrepreneurial intentions and personal traits

\begin{tabular}{|l|l|l|l|}
\hline Indp. Variables* & Std. Beta & t & Sig. \\
\hline Need for Achievement & .349 & 5.613 & .000 \\
\hline Locus of Control & .244 & 3.797 & .000 \\
\hline Entrepreneurial Self-Efficacy & .689 & 14.343 & .000 \\
\hline
\end{tabular}

Table 7. Results of the multiple linear regression concerning entrepreneurial intentions and contextual factors

\begin{tabular}{|l|l|l|l|}
\hline Indp. Variables* & Std. Beta & t & Sig. \\
\hline Educational Support & .211 & 3.246 & .001 \\
\hline Informal Support & .218 & 3.367 & .001 \\
\hline Formal Support & .313 & 4.967 & .000 \\
\hline
\end{tabular}


Table 8. Results of the multiple linear regression concerning the effects of personal traits and contextual factors on entrepreneurial intentions

\begin{tabular}{|l|l|l|l|}
\hline Indp. Variables* & Std. Beta & t & Sig. \\
\hline Personal Traits & .498 & 8.031 & .000 \\
\hline Contextual Factors & .111 & 1.786 & .075 \\
\hline
\end{tabular}
$\mathbf{R}^{2}: .31$
F: 50.682
P: .000

As shown in the Table 6, Table 7, and Table 8 model is statistically significant. Results of the regression analysis provided confirmation for the research hypotheses except $\mathrm{H}_{5}$. Based on the results of the statistical analysis, we can argue that approximately 31 percent of entrepreneurial intentions can be explained by mainly personal traits and contextual factors while remaining 69 percent can be explained by other variables that we have not considered in our research.

According to hypotheses tests, we can suggest that all variables except structural support are highly correlated with entrepreneurial intentions. Table 8 shows consolidated effects of personal traits and contextual factors on entrepreneurial intentions. Results have revealed that personal traits have stronger impact on entrepreneurial intentions compared to contextual factors. According to the results given above, al hypotheses except $\mathrm{H}_{5}$ are accepted.

Table 9. Hypotheses Test Results

\begin{tabular}{|l|l|l|}
\hline $\mathbf{H}_{\mathbf{1}}$ & $\begin{array}{l}\text { People with higher need for achievement motivation are more likely to have } \\
\text { a stronger intention to become entrepreneurs. }\end{array}$ & Accepted \\
\hline $\mathbf{H}_{\mathbf{2}}$ & $\begin{array}{l}\text { People with higher internal locus of control are more likely to have a } \\
\text { stronger intention to become entrepreneurs. }\end{array}$ & Accepted \\
\hline $\mathbf{H}_{3}$ & $\begin{array}{l}\text { People with higher entrepreneurial self-efficacy are more likely to have a } \\
\text { stronger intention to become entrepreneurs. }\end{array}$ & Accepted \\
\hline $\mathbf{H}_{4}$ & $\begin{array}{l}\text { Availability of perceived educational support have positive impact on } \\
\text { entrepreneurial intentions. }\end{array}$ & Accepted \\
\hline $\mathbf{H}_{5}$ & $\begin{array}{l}\text { Availability of perceived structural support have positive impact on } \\
\text { entrepreneurial intentions. }\end{array}$ & Rejected \\
\hline $\mathbf{H}_{6}$ & $\begin{array}{l}\text { Availability of perceived informal support have positive impact on } \\
\text { entrepreneurial intentions. }\end{array}$ & Accepted \\
\hline $\mathbf{H}_{7}$ & $\begin{array}{l}\text { Availability of perceived formal support have positive impact on } \\
\text { entrepreneurial intentions. }\end{array}$ & Accepted \\
\hline $\mathbf{H}_{\mathbf{8}}$ & $\begin{array}{l}\text { Personal traits have higher positive impact on entrepreneurial intentions } \\
\text { compared to contextual factors. }\end{array}$ & Accepted \\
\hline
\end{tabular}




\section{Conclusion}

According to the survey results, although the individual contextual factors are positively related to entrepreneurial intentions, contextual factors as a whole subset falls short in determining entrepreneurial intentions. As seen in Table 8, personal traits are better predictors of entrepreneurial intentions.

It is interesting to find that structural support was not perceived as a statistically significant predictor of entrepreneurial intentions. One possible reason for such a result is that the structural support mechanisms in Turkey is still developing. Although there have been many steps taken by the government in order to encourage entrepreneurship, we believe that introduced mechanisms and actions to support entrepreneurial activities are still very new that structural support is not perceived as a strong predictor of entrepreneurial intentions. Similary, in their research, Yurtkoru et al. (2014) could not found that a significant correlation between structural support and entrepreneurial intentions. They also note that the Turkish government recently developed incentives and educational programs for encouraging entrepreneurship in the society; however, these programs lead to the establishment of small businesses that lacks innovative initiatives.

Although educational support, informal and formal support were found as statistically significant predictors of entrepreneurial intentions, we can still argue that these contextual factors are not that different from the structural support. Because, universities have been only recently focusing on entrepreneurship education and again only recently started supporting entrepreneurial activities. Families, as an important informal support mechanism, still prefer that their children work for the government where the job security is perceived higher. According to Hofstede, risk avoidance score of Turkish culture is relatively high. In other words, Turkish culture does not support taking measurable risks. We believe that families' negative attitudes toward their children's entrepreneurial activities stem from this cultural profile. When it comes to formal support mechanisms, we could argue that they are also still developing like the structural support mechanisms.

Since the current status of contextual factors are as described above, although they are individually considered as important for entrepreneurial intentions, when compared to personal traits, they were seen as a weaker predictor of entrepreneurial intentions. On the other hand, personal factors such as need for achievement, locus of control, and entrepreneurial self-efficacy were seen as better predictors of entrepreneurial intentions. Similary, Sesen (2013) also found that personality traits of the respondents are more important than environmental factors for entrepreneurial intentions in Turkey. We strongly believe that personal traits will be seen as a better predictor for entrepreneurial intentions in Turkey until the mechanisms related to contextual factors are fully developed and widely accessible in the country.

\section{References}

Anderson, C. R. (1977). Locus of control, coping behaviors, and performance in a stress setting: a longitudinal study. Journal of Applied Psychology, 62(4), 446-451. 
https://doi.org/10.1037/0021-9010.62.4.446

Barbosa, S. D., Gerhardt, M. W., \& Kickul, J. R. (2007). The role of cognitive style and risk preference on entrepreneurial self-efficacy and entrepreneurial intentions. Journal of Leadership \& Organizational Studies, 13(4), 86-104.

https://doi.org/10.1177/10717919070130041001

Birley, S. (1985). The role of networks in the entrepreneurial process. Journal of Business Venturing, 1(1), 107-117. https://doi.org/10.1016/0883-9026(85)90010-2

Bosma, N., \& Kelley, D. (2018). Global Entrepreneurship Monitor 2018/2019 Global Report.

Botsaris, C., \& Vamvaka, V. (2016). Attitude toward entrepreneurship: structure, prediction from behavioral beliefs, and relation to entrepreneurial intention. Journal of the Knowledge Economy, 7(2), 433-460. https://doi.org/10.1007/s13132-014-0227-2

Boyd, N. G., \& Vozikis, G. S. (1994). The influence of self-efficacy on the development of entrepreneurial intentions and actions. Entrepreneurship: Theory and Practice, 18(4), 63-78. https://doi.org/10.1177/104225879401800404

Chen, C. C., Greene, P. G., \& Crick, A. (1998). Does entrepreneurial self-efficacy distinguish entrepreneurs from managers?. Journal of Business Venturing, 13(4), 295-316.

https://doi.org/10.1016/S0883-9026(97)00029-3

Chen, J. V., Su, B. C., \& Quyet, H. M. (2017). Users' intention to disclose location on location-based social network sites (LBSNS) in mobile environment: privacy calculus and Big Five. International Journal of Mobile Communications, 15(3), 329-353.

https://doi.org/10.1504/IJMC.2017.083465

Cover, J. D., \& Johnson, N. R. (1976). Need achievement, phase movement and the business cycle. Social Forces, 54(4), 760-774. https://doi.org/10.1093/sf/54.4.760

Cox, L. W., Mueller, S. L., \& Moss, S. E. (2002). The impact of entrepreneurship education on entrepreneurial self-efficacy. International Journal of Entrepreneurship Education, 1(2), 229-245.

Cunningham, J. B., \& Lischeron, J. (1991). Defining entrepreneurship. Journal of Small Business Management, 29(1), 45-61.

De Pillis, E., \& Reardon, K. K. (2007). The influence of personality traits and persuasive messages on entrepreneurial intention: A cross-cultural comparison. Career Development International, 12(4), 382-396. https://doi.org/10.1108/13620430710756762

Demirci, A. E. (2013). Cross-Cultural Differences in Entrepreneurial Tendencies: An Exploratory View in Turkey and Canada. International Journal of Entrepreneurship, 17, 21-40.

Engle, R. L. et al. (2010). Entrepreneurial intent: A twelve-country evaluation of Ajzen's model of planned behavior. International Journal of Entrepreneurial Behavior \& Research, 16(1), 35-57. https://doi.org/10.1108/13552551011020063 


\section{$\triangle 1$ Macrothink}

Business and Economic Research ISSN 2162-4860

Evans, D. S., \& Leighton, L. S. (1989). Some empirical aspects of entrepreneurship. The American Economic Review, 79(3), 519-535. https://doi.org/10.1007/978-94-015-7854-7_6

Fayolle, A., \& Liñán, F. (2014). The future of research on entrepreneurial intentions. Journal of Business Research, 67(5), 663-666. https://doi.org/10.1016/j.jbusres.2013.11.024

Fishbein. M., \& Ajzen, I. (1975). Belief, Attitude, Intention and Behavior: An Introduction to Theory and Research. Addison-Wesley. Reading.

Gartner, W. B. (1988). "Who is an entrepreneur?" is the wrong question. American Journal of Small Business, 12(4), 11-32. https://doi.org/10.1177/104225878801200401

Gelard, P., \& Saleh, K. E. (2011). Impact of some contextual factors on entrepreneurial intention of university students. African Journal of Business Management, 5(26), 10707-10717. https://doi.org/10.5897/AJBM10.891

Gurol, Y., \& Atsan, N. (2006). Entrepreneurial Characteristics Amongst University Students. Education \& Training, 48(1), 25-38. https://doi.org/10.1108/00400910610645716

Hansemark, O. C. (1998). The effects of an entrepreneurship programme on need for achievement and locus of control of reinforcement. International Journal of Entrepreneurial Behavior \& Research, 4(1), 28-50. https://doi.org/10.1108/13552559810203957

Holland, J. L. (1985). Making Vocational Choices. Prentice Hall. Englewood Cliffs

Hussain, S. (2018). Towards nurturing the entrepreneurial intentions of neglected female business students of Pakistan through proactive personality, self-efficacy and university support factors. Asia Pacific Journal of Innovation and Entrepreneurship, 12(3), 363-378. https://doi.org/10.1108/APJIE-03-2018-0015

Ismail, M., Khalid, S. A., Othman, M., Jusoff, H. K., Rahman, N. A., Kassim, K. M., \& Zain, R. S. (2009). Entrepreneurial intention among Malaysian undergraduates. International Journal of Business and Management, 4(10), 54-60. https://doi.org/10.5539/ijbm.v4n10p54

Jackson, D. N. (1974). Personality Research Form Manual. Research Psychologists Press. Port Huron.

Khoshmaram, M., Shiri, N., Shinnar, R. S., \& Savari, M. (2020). Environmental support and entrepreneurial behavior among Iranian farmers: The mediating roles of social and human capital. Journal of Small Business Management, 1-19. https://doi.org/10.1111/jsbm.12501

Koh, H. C. (1996). Testing Hypotheses of Entrepreneurial Characteristics: A Study of Hong Kong MBA Students. Journal of Managerial Psychology, 11(3), 12-25.

https://doi.org/10.1108/02683949610113566

Kolvereid, L., \& Moen, O. (1997). Entrepreneurship among business graduates: Does a major in entrepreneurship make a difference?. Journal of European Industrial Training, 21(4), 154-160. https://doi.org/10.1108/03090599710171404

Krueger, N. F. (1993). The impact of prior entrepreneurial exposure on perceptions of new 
venture feasibility and desirability. Entrepreneurship Theory and Practice, 18(1), 5-21. https://doi.org/10.1177/104225879301800101

Krueger, N. F. (2017). Entrepreneurial intentions are dead: Long live entrepreneurial intentions. In Revisiting the Entrepreneurial Mind (pp. 13-34). Springer, Cham.

https://doi.org/10.1007/978-3-319-45544-0_2

Levenson, H. (1981). Differentiating among internality, powerful others, and chance. In H. M. Lefcourt (Ed.), Research with the locus of control construct (Vol. 1, pp. 15-63). New York: Academic Press. https://doi.org/10.1016/B978-0-12-443201-7.50006-3

Locke, E. A., Latham, G. P., \& Erez, M. (1988). The determinants of goal commitment. Academy of Management Review, 13(1), 23-39. https://doi.org/10.5465/amr.1988.4306771

Loon, M., \& Casimir, G. (2008). Job-demand for Learning and Job-related Learning the Moderating Effect of Need for Achievement. Journal of Managerial Psychology, 23(1), 89-102. https://doi.org/10.1108/02683940810849684

Marire, E., Mafini, C., \& Dhurup, M. (2017). Drivers of entrepreneurial intentions amongst generation Y students in Zimbabwe. International Journal of Business and Management Studies, 9(2), 17-34.

McClelland, D. C. (1967). The Achieving Society. New York. Free Press. https://doi.org/10.1111/j.1540-6520.2009.00304.x

McGee, J. E., Peterson, M., Mueller, S. L., \& Sequeira, J. M. (2009). Entrepreneurial selfefficacy: refining the measure. Entrepreneurship Theory and Practice, 33(4), 965-988.

Ören, K., \& Biçkes, M. (2011). Kişilik özelliklerinin girişimcilik potansiyeli üzerindeki etkileri (Nevşehir'deki yüksek öğrenim öğrencileri üzerinde yapılan bir araştırma). Süleyman Demirel Üniversitesi İktisadi ve İdari Bilimler Fakültesi Dergisi, 16(3), 67-86.

Rauch, A., \& Frese, M. (2007). Let's put the person back into entrepreneurship research: a meta-analysis on the relationship between business owners' personality Traits, business creation, and success. European Journal of Work and Organizational Psychology, 16(4), 353-385. https://doi.org/10.1080/13594320701595438

Rotter, J. B. (1966). Generalized expectancies for internal versus external control of reinforcement. Psychological Monographs: General and Applied, 80(1), 1-28. https://doi.org/10.1037/h0092976

Saeed, S., Yousafzai, S.Y., Yani-De-Soriano, M. and Muffatto, M. (2015). The role of perceived university support in the formation of students' entrepreneurial intention. Journal of Small Business Management, 53(4), 1127-1145. https://doi.org/10.1111/jsbm.12090

Saroglou, V., \& Muñoz-García, A. (2008). Individual differences in religion and spirituality: An issue of personality traits and/or values. Journal for the Scientific Study of Religion, 47(1), 83-101. https://doi.org/10.1111/j.1468-5906.2008.00393.x

Schwarz, E. J., Wdowiak, M. A., Almer-Jarz, D. A., \& Breitenecker, R. J. (2009). The effects 


\section{Macrothink

of attitudes and perceived environment conditions on students' entrepreneurial intent: An Austrian perspective. Education \& Training, 51(4), 272-291. https://doi.org/10.1108/00400910910964566

Sesen, H. (2013). Personality or environment? A comprehensive study on the entrepreneurial intentions of university students. Education+Training, 55(7), 624-640. https://doi.org/10.1108/ET-05-2012-0059

Shankar, N. (2014). Effect of social factors, entrepreneurial behavior towards entrepreneurial intention among law graduates. International Journal of Management Research and Reviews, $4(2), 215-220$.

Van Gelderen, M., Brand, M., van Praag, M., Bodewes, W., Poutsma, E., \& Van Gils, A. (2008). Explaining entrepreneurial intentions by means of the theory of planned behaviour. Career Development International, 13(6), 538-559.

https://doi.org/10.1108/13620430810901688

Yurtkoru, E. S., Kuşcu, Z. K., \& Doğanay, A. (2014). Exploring the antecedents of entrepreneurial intention on Turkish university students. Procedia-Social and Behavioral Sciences, 150, 841-850. https://doi.org/10.1016/j.sbspro.2014.09.093

Zhao, H., Seibert, S. E., \& Hills, G. E. (2005). The mediating role of self-efficacy in the development of entrepreneurial intentions. Journal of Applied Psychology, 90(6), 1265-1272. https://doi.org/10.1037/0021-9010.90.6.1265

Zimmer, C. (1986). Entrepreneurship through social networks. The Art and Science of Entrepreneurship. Ballinger, Cambridge, 3-23.

\section{Copyright Disclaimer}

Copyright for this article is retained by the author(s), with first publication rights granted to the journal.

This is an open-access article distributed under the terms and conditions of the Creative Commons Attribution license (http://creativecommons.org/licenses/by/4.0/). 